\title{
Policies related to access to higher education and work: academic education in question
}

\author{
Políticas de acesso à educação superior e ao trabalho: a \\ formação em questão
}

\section{Maria Lourdes Gisi ${ }^{[a]}$, Gisele do Rocio Cordeiro ${ }^{[b]}$, Angela Sugamosto Westphal[c]*}
[a] Pontifícia Universidade Católica do Paraná (PUCPR), Curitiba, PR, Brasil
[b] Centro Universitário Internacional (UNINTER)
[c] Coordenação de Aperfeiçoamento de Pessoal de Nível Superior (CAPES)

\begin{abstract}
The aim of this study is to investigate the policies related to access to higher education and work, and more specifically the relation between these policies and the requirements of the current society in terms of the education process. Such requirements are considered in a context strongly related to economic development, in the attempt to align the education process to market requirements only. Developing an academic education program
\end{abstract}

MLG: Doutora em Educação, e-mail: gisi.marialourdes@gmail.com

GRC: Mestre em Educação, e-mail: gisele.c@uninter.com

ASW: Mestre em Educação, e-mail: angelasugamosto@gmail.com 
committed to the acquisition of knowledge, which contributes to preparing for work and the emancipation of the human being, is a current challenge. Thus, research was conducted, using a focus group of 20 professors who work in higher education. From the testimonies, it was possible to identify four categories: characteristics of the labor market, professional requirements, characteristics of academic formation, and academic formation requirements. The data make evident the need to contemplate a contextualized and interdisciplinary education process to contribute to overcoming educational inequalities and to allow young people to access work.

Keywords: Educational politics. Higher education. Formation.

\section{Resumo}

O objeto de estudo desta pesquisa são as políticas de acesso à educação superior e ao trabalho, mais especificamente a relação dessas políticas com os requisitos da sociedade atual em relação ao processo formativo. Tais requisitos são considerados em um contexto fortemente vinculado ao desenvolvimento econômico, na tentativa de adequar o processo de formação tão somente aos requisitos do mercado. Desenvolver uma formação comprometida com a aquisição de conhecimentos, que contribuem com o preparo para o trabalho e com a emancipação do ser humano, é o desafio que se apresenta na atualidade. Nessa perspectiva, foi realizada uma pesquisa com 20 professores que atuam na educação superior, mediante grupo focal. A partir dos depoimentos, foi possível identificar quatro categorias: características do contexto de trabalho; requisitos profissionais; características da formação; requisitos da formação. Os dados deixam evidente a necessidade de contemplar um processo educacional contextualizado e interdisciplinar de modo a contribuir com a superação das desigualdades educacionais e favorecer o acesso dos jovens ao trabalho.

Palavras-chave: Política educacional. Educação Superior. Formação. 


\section{Introduction}

This study involves a reflection on the process of academic education in higher education, considering the conflicting messages about the appropriate academic education for young people, given the requirements of today's society. It is assumed that academic education for the labor market cannot have economic development as its main focus, as stated in the documents of international organizations, especially the World Bank and the OECD. Additionally, it is important to consider the changes that have taken place while organizing work at a global level, which have had a profound impact on young people's access to work. It is a new reordering of the process of accumulation "[...] at an international level, which takes place in industrial zones [...] and the scientific and technological revolution through the processes of cybernetic modernization, chemistry and automation that modify the productive structure and the organization of work" (FRANCO, 2000, p. 206).

It is evident that such changes occur to a greater or lesser extent and scope, depending on the type of organization and the economic policies implemented in different countries; however, the need for a new worker with skills that encompass technical-scientific knowledge, including tacit knowledge, is common across all social spheres ${ }^{1}$.

It is observed that schooling was already essential for the labor market during the Industrial Revolution in the eighteenth century, when new types of organizations required basic academic education. However, until the mid-1950s, there was no understanding of the fact that education was an important variable for countries' economic development, which changed especially with the influence of the studies of Schultz

1 Based on the studies of Nonaka and Takeuchi, Santos (2004, p. 7) indicates that tacit knowledge is rooted in the experiences, values, and emotions of individual and therefore comprises a technical and a cognitive dimension, with the latter understood as a representation of reality and a projection of how it should be in the future. This knowledge, which is based on the experience of individuals in a given professional area, has been highly valued as a fundamental component of the competences of professionals in the labor market. 
(1973), Becker (1993), Apud Viana and Lima (2010) on human capital theory. According to Viana and Lima (2010, p. 2), from these studies, it was observed that there was another factor responsible for the economic growth of countries, besides those related to production (natural resources, capital and labor), which was called human capital. Thus, investing in education, by improving workers' qualifications, would result in higher productivity and consequently in profit increases, benefiting individuals and their countries' economies.

Samuel Bowles and Herbert Gintis (2002), in "Schooling in Capitalist America", also discussed the influence of education on economics from another perspective, stimulated by heated academic debates about structure and purposes of education, which began in 1968, when the theory of human capital was debated. In initial studies on this subject, authors believed that education could contribute to a more productive economy. Their research has shown, however, that the contribution of education to the success of the economy is only partly explained by the cognitive skills learned in school. What the authors propose is that schools prepare people for the rules of adult work by socializing them to function well and without complaint, within the hierarchical structure of the modern corporation. This phenomenon is referred to by the authors as the correspondence principle, i.e., structuring social interactions and individual rewards, which replicate the working environment (BOWLES; GINTIS, 2002, p. 1, emphasis in the original).

Alternatively, Bourdieu and Passeron (2008, p. 236), writing shortly after the previous authors in 1970, discuss how the school reproduces class inequalities by considering that:

The education system can only free itself so perfectly from its ideological function of legitimizing the established order because this masterpiece of social mechanism succeeds in concealing, as by a double-bottomed box, the functions which, in a society divided into classes, unite the function of inculcation, i.e., the function of intellectual and moral integration, to the function of conservation of the characteristic structure of class relations of that society. 
Even though Bowles and Gentis' analyses show that the school contributes to the capitalist system, the major emphasis of these writers is on the appropriateness to the rules of organization and functioning of that system. For Bourdieu and Passeron, the school reproduces social inequalities, as it does not contemplate young people from adverse social and economic conditions in the schooling process. Both analyses consider the fact that the school plays a role that goes beyond the development of specific skills to act in the labor market.

The relationship between individuals and the labor market goes back to the establishment of the market that occurred, as Benjamin (2012, p. 7) mentions, in the modern era, when the relationship between man and nature came to be based on the economic system.

Production and distribution of material goods have always existed rooted in social relationships of a non-economic nature. As, for example, kinship relations. Rupture only occurred in the modern world, when the expanding mercantile elements merged and swallowed up the workforce and the earth - i.e., man and nature - an unprecedented fact in history. Society and its environment have become market accessories, now an autonomous mechanism. "Instead of the economy being rooted in social relations," as it always did, "social relations began to take root in the economic system" (BENJAMIN, 2012, p. 7, emphasis in the original).

The separation of the nineteenth-century economic system the rest of society was, according to Polanyi (2012), an important characteristic, because, in a market economy, the production and distribution of material goods are governed by its laws and motivated, ultimately, by two simple incentives: "the fear of hunger and the hope of profit" (p. 95). This author presents a description of the shift from an old status-based society to a modern contract-based society. Status is acquired at birth "[...] by the position of and in the family" in that society. The rights and duties of the individual derive from his position, and in the case of a contract-based society, rights and duties are "stipulated by consensual transactions, or 
contracts" (p. 96). Since then, status no longer guarantees the participation of individuals in the system, as its incentives are purely economic.

However, in a study of 98 undergraduates and graduates of a Business Administration course, Lemos, Dubeux, and Pinto (2009, p. 375385 ) investigated the validity of Bourdieu's propositions that there is not necessarily a relation between academic education and employability when it comes to students from the bottom of the social stratum, with a tendency to reproduce social inequalities. One of the aspects considered was how the participants in the research had access to jobs or internships. Two-thirds of the individuals with the lowest household income reported that they obtained the vacancy by attending formal recruitment processes, and only $15 \%$ of them were indicated by acquaintances and relatives; among those with the highest family income, $43 \%$ were indicated by acquaintances and relatives, while $11 \%$ worked in family business. Thus, the authors conclude that social capital enhances the ability of the holders of cultural capital to convert the higher education received into economic capital. According to Pochmann and Antunes (2008), "In 2002, for example, 62\% of the unemployed belonged to low-income families, with the remainder divided into middle-class (32.4\%) and upper-middle class (5.6\%) families". Such studies seem to indicate that the status of individuals still contributes to social mobility, which in some way contradicts the theory of human capital.

Currently, according to Gentili (2005, pp. 47-8), the theory of human capital, in its classical formulation, is exhausted because of its re-signification in contemporary society. At the time it was proposed, this theory was based on a conjuncture of economic growth and the strengthening of the Welfare State, in which the school was considered "[...] a powerful institutional device of social integration in a broad sense." However, in the 1970s, the economic crisis in capitalist societies, with its impacts on the following decades, promoted "[...] coexistence, although conflicting, between education and unemployment."

Over the years, a great variation has been observed in the relationship between schooling and work; but, according to Pochmann (2010, p. 
173), "[...] one cannot lose sight of the transition to a post-industrial society that considers knowledge as the main strategic asset regarding income and wealth." The author considers that higher education has become the basis for entering the labor market and an essential education throughout life. Although there is no direct relationship between having a higher education diploma and access to work, it seems that nowadays it is even more difficult to enter the labor market for young people without a college degree.

According to the International Labor Organization, of the total number of unemployed, 75 million (40\%) are young. It is estimated that 152 million young people live on less than $\$ 1.25$ a day, which, combined with the number of youth unemployed, reaches 227 million young people in extreme vulnerability (ILO, 2013). Changes related to the unemployment situation require greater state intervention in the definition of policies, especially regarding economic policy ${ }^{2}$, and greater investment in education, as advocated by the International Labor Organization:

[...] los países más adelantados el logro educativo, medido por el promedio de años de escolaridad, precedió la transformación productiva. Los países con niveles de escolaridad más bajos tienen cuotas mucho menores de producción industrial en el PIB. Los países con niveles de escolaridad más altos tienen cuotas más altas y mayores niveles de diversificación. Por lo tanto, los vínculos entre políticas de educación y formación por una parte, y las políticas de transformación productiva, por otra deberían ser evidentes. Un proceso de progreso con alto coeficiente de empleo trata de promover procesos de aprendizaje y actualización veloces. (OIT, 2013).

According to the Brazilian Institute of Geography and Statistics (IBGE) (2016), "The labor market registered an increase of $11.1 \%$ of the employed population aged 16 years or more between 2005 and 2015"; however,

2 "[...] un cambio fundamental en la mentalidad de los donantes y de las instituciones financieras internacionales (IFIs) hacia la aceptación de un papel más activo del Estado en la economía, incluyendo políticas macroeconómicas más favorables al empleo" (OIT, 2013). 
the population in this same age group experienced an even greater growth (19.1\%) in the same period. Thus, it can be observed that those who suffered most from unemployment were young people aged 16 to 24 (BRASIL, 2016).

Regarding access to higher education, which could provide greater access to work, it is observed that, with the changes resulting from the LDB (Law of Guidelines and Bases of Education), there was a significant increase in enrollments, courses, and institutions of higher education, especially private institutions. According to the latest census of higher education available for consultation (2015), enrollments in private institutions have reached a new level: of 8,027,297 enrollments, 6,075,157 were in private institutions (BRASIL, 2016).

Although there has been a significant increase in higher education institutions and courses, access to higher education for young people aged 18 to 24 is still an issue in Brazil. The 2015 Higher Education Census indicated that $17.6 \%^{3}$ of young people enrolled in higher education (BRASIL, 2015). Considering the population as a whole, only $7.9 \%$ have a higher education diploma, from which it can be deduced that access policies are a real priority in the country. According to data from the IBGE, in 2011 , only $12.5 \%$ of workers had a full university degree (BRASIL, 2012).

Pochmann (2010, p. 164-175) considers the fact that one of the great challenges facing Brazil is ensuring productive and educational investment to support basic and higher education, even though there is no guarantee of access to the labor market for highly-educated individuals in today's society. The author, when referring to the difficulties of access to this level of education, indicates that poor young people do not exceed five years of schooling, which is an obstacle to their social mobility.

The inclusion of young people in the labor market today has been a major challenge, which has prioritized policies related to access to higher education and adapting the education process to the requirements of the market in Brazil.

3 According to Brasil (2012), based on data from the National Household Sample Survey (PNAD), in 1995 , only $5.9 \%$ of young people aged 18 to 24 were enrolled in higher education. 
Origins of inequalities in the Brazilian labor market date back to its formation in the 1930s and to the characteristics of its subsequent development, which can be broadly defined as especially concentrated and restricted to the incorporation of skilled workers tied to urban activities (POCHMANN APUD; BRASIL, 2013b, p. 140).

According to the IBGE's Social Indicators Synthesis (2013b, p. 140), "Work is a central and structuring element of social and economic relations established in societies." Its knowledge is an important source of understanding of the social and economic situation of the population, especially given the characteristics of the labor market in Brazil, which "[...] occurs in a differentiated way, which implies, in differentiated incomes and, thus, unequal access to the market for goods and services."

The position of individuals in the labor market is an important factor for social integration and the point from which the social and cultural assets of a capitalist society are established. The configuration of the labor market, in turn, is concerned about the way in which social relations were established during countries' development. Brazil still has a fragmented and heterogeneous labor market, which was analyzed in depth by Barbosa (2008), in his book The formation of the labor market in Brazil.

In his study, the author indicated in detail how the labor market was formed in the country from $1930^{4}$, when national policies for regulation of labor were established. Before this period, although some labor regulation initiatives were observed, these included only certain professional categories or specific regions.

4 The author seeks to develop the study from three stages: “[...] the non-labor market of the colonial period, the construction of regionally fragmented and incomplete labor markets from 1889 to 1930, before it became feasible nationalization and consolidation from 1930 onwards." It sought to capture the process of construction of the labor market in Brazil and to highlight the slavery period, transition from slave labor to "free labor," the whole process of immigration of foreign workers and the relation of this period to the constitution of the labor market. 
Another important aspect is state intervention in '[...] all stages of construction of the labor market.' According to Barbosa (2008, p. 21), the state appeared:

[f]irst, enacting the end of traffic. Then, by ensuring that re-enslavement was done in a more "quiet" way. Later on, it financed the increase of imported labor and defended a federalist liberalism that stifled the privatism of social and labor relations. Finally, by taking the social question for itself, by withdrawing it from direct class confrontation, but without eliminating it, and by establishing "social prices" that allowed the expanded reproduction of capital on a national scale (BARBOSA, 2008, p. 21). (Quotation marks in the original).

The constitution of the labor market in Brazil, although with important intervention from the state, was characterized as heterogeneous across the different regions of the country, according to the specificities of each region of interest of the national and international elite, which is evident to this day.

Barbosa (2008, p. 159) also explained that the transition from a non-labor market to a national labor market would go through two stages: "[...] a first one involving the end of the slave trade until abolition and a second implying the formation of lame, incomplete and regionally fragmented labor markets." In this trajectory, according to the author, the inheritance of slavery showed different characteristics in different regions, with the presence of the state and the authoritarianism of the "quasi-employers."

Pochmann (1998, p. 120), in turn, while analyzing the configuration of the labor market up to the 1980 s, indicated problems related to two dimensions: the first one, associated with traditional labor market problems, such as "[...] a) still compressed wage rates, b) low wages, c) high informality and d) high underemployment." The second dimension, according to the author, refers to the structural employment characteristic of "[...] industrialization, rural migration and national urbanization [causing] a high surplus of labor." 
In the 1990s, according to Barbosa (2008), a return to the past is not observed, but rather "[...] new realities already enunciated, as in a deformed mirror, in the period of origin of our capitalism." The author refers to the reduction of wage rates, informality, unemployment, and the regression of labor and social rights. Currently, the configuration of the labor market is still heterogeneous and fragmented, with low wages, and the strong presence of informality, which makes the access even more difficult for those who did not have the opportunity to access higher education.

According to the IBGE, there is also a great variation in the income of workers across Brazilian regions, and inequalities in the labor market exist regarding gender, color or race, regional location, educational background, among others. As one study showed, "Regarding the issue of color or race, a striking feature is the greater proportion of blacks or browns in informal jobs (49.6\%), when compared to the white population (36\%)" (BRASIL, 2013, p. 150).

Although there has been an improvement in the percentage of people employed in formal work, regional disparity is still significant, especially when comparing the Southeast with the North and Northeast.

\section{Methodology}

The research ${ }^{5}$ was developed from a qualitative approach that, according to Giroulx (2010), allows using new perspectives and interpretations closer to the contexts of situations, bringing new clarifications to the subject under study. The decision was made to hold a focus group with three groups of professors from higher education institutions, comprising twenty professors in total. Two meetings were held with each group of professors.

The choice of this technique allowed professors' "perceptions of the subject investigated by identifying participants" and their perception

5 The focus group was attended by two PIBIC students: Otavia Maria Kreitlow Basso and Andrey Alves Kochake. 
of the education process to be revealed. The focus group technique favors the deepening of a subject, as more than one meeting is held with the same group in which the debate on the subject among the participants is allowed (GATTI, 2005; LERVOLINO; PELICIONI, 2001).

The professors participating in the research were deliberately chosen from different areas of knowledge, including Pedagogy, Mathematics, Social Sciences, Civil Engineering, Physical Education, Economics, Veterinary Medicine, Animal Science, Physics, Geography, Law, Public Relations, Journalism, and Philosophy. The meetings were scheduled in advance, requiring the meeting times to be matched with the expected number of participants for the study.

The focus group setting was a classroom with appropriate space for the research. Arranging participants in a circle with the presence of the group mediator aimed to stimulate debate and to restrict the subject addressed by the research, i.e., the mediator could intervene to avoid the participants deviating from the central subject. From the beginning, the participants were informed that the research would be fully recorded using audio recorders and, with their complete approval, the Informed Consent Form was distributed so that they could sign it and be made aware of the research objectives.

From the recordings of the groups' meetings, audios were transcribed for later reading and analysis, generating tables and four content categories reflecting some of the testimonies: characteristics of the labor market; professional requirements; characteristics of vocational academic education; academic education requirements.

\section{Perception of the education process}

a) Characteristics of the labor market

A competitive and demanding work environment was mentioned in the participants' reports, characterized by a decreasing number of 
jobs with a formal contract, the expansion of outsourcing, a diversified labor market, and the expansion of autonomous work (i.e., entrepreneurship largely stimulated). Their reports are outlined below:

It is much harder; the competition is so fierce in the pursuit of what I call a multi functional professional, he cannot be limited, he does not have anyone to help him using the computer, Excel, and social media. (C) Technology has greatly changed the profile of professions. Today we know that many people work at home on the Internet, which was unthinkable years ago ; this will continue until technology assumes certain people's positions, and can provide other possibilities that people do not see yet. (M)

Although there is no direct link between having a higher education diploma and access to work, it seems that for young people without a college education it is even more difficult to access the labor market nowadays.

b) Professional Requirements

Professional experience is considered to be of paramount importance nowadays, and one of the ways of obtaining such experience cited by participants was through an internship. Internships during academic education, as well as postgraduate courses, mastery of a second language, and computer skills, were considered to be minimum requirements. Professionals with a distinct skill - such as proactivity, autonomy (multifunctional professional), initiative, interest and creativity, interpersonal relationship skills, dedication (fly the flag of the company), and knowledge of technological tools - were also mentioned. Some of the reports were as follows:

Nowadays they ask for specialization, experience, knowledge in a second language. [...] today the labor market is more selective, it looks for professionals of excellence, especially those with experience. (D) 
The labor market looks more for people who have the capacity for evolution, adaptation, and leadership, rather than those with technical education, only if it is a very specific training, technically speaking. Otherwise, companies prefer to bet that the person will learn and will develop himself [evolve]. (L)

c) Characteristics of academic formation

The participants consider that, in many situations, the teaching methodology is inadequate, the curriculum is organized by disciplines in isolation, students are passive, professors are resistant to change, academic education is centered on content transmission without direct relation to professional practice, higher education institutions are mercantilist, there is a dichotomy between basic and higher education, and curricular reforms are made without professors' participation. They also mentioned the responsibility of the government, the confused identity of middle school with precarious conditions of content, the formation of values, and preparation for the labor market (PAIVA; SILVA, 2013, p. 54). Some of the participants' reports are provided below:

I believe that we have a lot to improve, I realize that we work in a very fragmented way in the university, each one doing their part ... (J)

[...] the student arrives from high school with no autonomy, most of the students, I would say $90 \%$, have huge difficulty abandoning an expository [classroom] format and seeing himself as part of the process. (M)

I think education today has to undergo a process of radical change, it organizes itself [as] a system of production of industry in large chains of production, series and cycles, periods and stages [...] quality control. I think there is a lot of state control over teaching [...] control of grades, presence, all of this is regulated, and the institution does not have the autonomy to create new assessment techniques. Moreover, the institution does not have autonomy to decide on how many school days it will work. (I) 
I work in several universities, some of them are merely mercantilists, [...] they prepare with the minimum knowledge required to put the individual at the disposal of society; however, there are also institutions concerned with academic education people so that they enter society with quality education and can be professionals who seek just that, and autonomous professionals who seek more and more knowledge. (D)

d) Requirements of academic formation

The research participants considered essential to match a theoretical and reflexive foundation with the demands of the professional arena, by using new interactive technologies, contextualizing teaching, introducing project methodology, introducing self-evaluation for professors, motivating students, and seeing the professor as mediator. One such comment is shown below:

[...] the institution has to be concerned about the outside reality of that professional, [...] it has to have a curriculum that meets today's challenges of education. However, it is noteworthy, regarding the academic education, that the student also has to seek it. [...] institutions have to seek and train professionals with greater freedom of autonomy, knowledge, criticism, reflection, contextualization and, above all, seeing the whole. (D)

\section{General Considerations}

Education is permeated by the contradictions of a society that seeks to secure social rights through extensive legislation, but has little power of intervention to enforce such rights. Besides these issues, it is worth noting the direction given by educational policies, which follow many of the guidelines of the international organizations, which consider that education should only be concerned with the requirements of economic development. 
Another aspect related to the academic education of young people is very well analyzed by Coêlho (2016, p. 94-95), who warns about the type of academic education that continues to be developed as if it were possible to know how society will be in the years to come. He suggests that it would be more reasonable to aim for "[...] a formation of people who can read, study, write, understand and think about the natural and human world, collective life, action, ideas, and practice [...]" Moreover, such academic education would require knowledge of the fundamental questions in different areas of knowledge, according to the course chosen and the future area of work.

This is certainly not an easy task since it requires an education process that, in a broad perspective, favors the connection between theoretical and practical and an interdisciplinary pedagogical proposal within the domains of technical-scientific knowledge, social responsibility, and ethical action. Educational policies that contemplate basic and higher education in an interconnected way, such as a true National Education System, is of fundamental importance in making this education process viable.

\section{References}

BARBOSA, A. F. A formação do mercado de trabalho no Brasil. São Paulo: Alameda, 2008.

BENJAMIN, C. Nota da edição brasileira. In: POLANYI, K. A subsistência do homem e ensaios correlatos. Organização de LEVITT, K. P. Rio de Janeiro: Contraponto, 2012. p. 7-10.

BOURDIEU, P.; PASSERON, J.-C. A reprodução: elementos para uma teoria do sistema de ensino. Petrópolis/RJ: Vozes, 2008.

BOWLES, S.; GINTIS, H.; Schooling in capitalist América. Sociology of Education, v. 75 , n. 1, jan. 2002, p. 1-18. 
BRASIL. IBGE. Censo Demográfico 2010. Disponível em: <http://www.ibge.gov. br>. Acesso em: 4 jul. 2013.

BRASIL. IBGE. Pesquisa Nacional por Amostra de Domicílio (PNAD), 2012. Disponível em: <http://Acesso em: 4 ago. 2013.

BRASIL. INEP. Censo da Educação Superior/2015. Disponível em: <http://www. mec.gov.br>. Acesso em: 1 jun. 2017.

BRASIL. INEP. Censo da Educação Superior/2013. Disponível em: <http://www. mec.gov.br>. Acesso em: 1 jun. 2016.

BRASIL. Síntese de Indicadores Sociais: uma análise das condições de vida da população brasileira. IBGE. Coordenação de população e indicadores sociais. Rio de Janeiro: IBGE, 2016

COÊLHO, I. A. Universidade e ensino: treino ou formação? In: COÊLHO, I. M.; FURTADO, R. M. M. Universidade, cultura, saber e formação. Campinas/SP: Mercado de Letras, 2016.

FRANCO, M. C. Quando nós somos o outro: questões metodológicas sobre estudos comparados. Educ. Soc. v. 21, n. 72, Campinas, Ago. 2000, p. 197-208.

GENTILI, P. Três teses sobre a relação trabalho e educação em tempos neoliberais. In: LOMBARDI, J. C.; SAVIANI, D.; SANFELICE, J. L. (Org.). Capitalismo, trabalho e educação. 3. ed. Campinas: Autores Associados, Histedbr, 2005. p. 45-59.

GEROULX, L.-H. Contribuição da pesquisa qualitativa à pesquisa social. In: POUPART, Jean e Cols. A pesquisa qualitativa: enfoques epistemológicos. 2. ed. Petrópolis: Vozes, 2010. p. 95-124.

LEMOS, A. H. C.; DUBEUX, V. J.; PINTO, M. C. S. Educação, empregabilidade e mobilidade social: convergências e divergências. Cadernos EBAPE, v. 7, n. 2, jun. 2009, p. 369-384. 
LERVOLINO, S. A.; PELICIONI, M. C. A utilização do grupo focal como metodologia qualitativa na promoção da saúde. Revista da Escola de Enfermagem, USP, v. 35, n. 2, p. 115-21, jun. 2001. Disponível em: 〈http://www.scielo.org.br〉. Acesso em: 22 set. 2013.

OIT. Organização Internacional do Trabalho. Emprego. Disponível em: <http:// www.oit.org.br>. Acesso em: 14 ago. 2013.

POCHMANN, M.; ANTUNES, R. Dimensões do desemprego e da pobreza no Brasil. INTERFACEHS - Revista de Gestão Integrada em Saúde do Trabalho e Meio Ambiente, v. 3, n. 2, abr./ago. 2008, p. 1-10. Disponível em: <http://www.interfacehs.sp.senac.br>. Acesso em: 4 set. 2013.

POCHMANN, M. Velhos e novos problemas do mercado de trabalho no Brasil. Indicadores Econômicos FEE, Porto Alegre: Fundação de Economia e Estatística FEE, v. 26, n. 2. p. 119-139, 1998. Disponível em: <http://revistas.fee.tche.br/ index.php/indicadores/article/view/1297/1665>. Acesso em: 11 nov. 2014.

POCHMANN, M. Desenvolvimento e perspectivas novas para o Brasil. São Paulo: Cortez, 2010.

POLANYI, K. A subsistência do homem e ensaios correlatos. Organização de LEVITT, K. P. Rio de Janeiro: Contraponto, 2012.

SANTOS, M. F. T. Teoria do capital intelectual e teoria do capital humano: estado, capital e trabalho na política educacional em dois momentos do processo de acumulação. Anais da 27ª Reunião Anual da ANPED, Caxambu - MG, 2004.

VIANA, G.; LIMA, J. F. Capital humano e crescimento econômico. Interações. Campo Grande, v. 11, n. 2 jul./dez. 2010. Disponível em: <http://www.scielo.br>. Acesso em: 27 jun. 2013.

Received:05/09/2017

Recebido: 09/05/2017

Approved:06/05/2017

Aprovado: 05/06/2017 